\title{
Tax Stability in Morocco
}

\author{
Tahri Firdawss ${ }^{1} \&$ Karim Mohamed ${ }^{1}$ \\ ${ }^{1}$ EREMEPP, University of Mohammed V, Rabat, Morocco \\ Correspondence: TAHRI Firdawss, EREMEPP, University of Mohammed V, Rabat, Morocco. E-mail: \\ t.firdawss@gmail.com
}

Received: November 21, 2019

Accepted: December 30, 2019 Online Published: December 31, 2019

doi:10.5539/ijef.v12n1p90

URL: https://doi.org/10.5539/ijef.v12n1p90

\begin{abstract}
This paper aims to lead a reflection on Moroccan tax system stability, which is an important factor that promotes sustainability of public finance. Therefore, an assessment of the relationship between tax revenues and national GDP was conducted first, in order to get a global overview of the stability of the Moroccan tax system. Afterwards, we examine the empirical measure of each of the concepts, stability, growth rate and stabilizing influence for tax revenues in Morocco. The study focused on value added tax (TVA), IS (corporate tax), IR (income tax), and internal tax on consumption (TIC) over the period 1990-2017. The results demonstrate a good performance of tax revenues in terms of stability over the period 1990-2017, and shows that the Moroccan tax system includes taxes that generate stable current income (TIC and TVA), as well as elastic taxes correlated with economic growth (IS and IR).
\end{abstract}

Keywords: Moroccan tax system, reform, economic growth, elasticity

\section{Introduction}

Moroccan tax system is a constantly reforming field. With each law of finance, new tax adjustments are introduced to improve economic incentives and to address economic, social and governance challenges. Nevertheless, policy makers should consider stability, alongside simplicity and certainty, when they are making decisions to change the tax system.

Indeed, a well-designed tax system encourages competitiveness in the various sectors of the economy, to stimulate stronger economic growth. This goal can be achieved by increasing savings and leading to investments with high-return activities. However, taxes should neither create major distortions in consumption and production behavior nor change private investment decisions, they should be neutral.

In addition, taxes are supposed to be sufficient to fund the government's spending needs over time. In fact, revenues are expected to increase with national income, and the overall tax system should evolve to improve revenues over time. As a result, tax revenues are expected to increase at the same rate as GDP growth. Therefore, the government should adopt tax policies that include sectors of the economy with a growing tax base.

\section{Main Developments in the Moroccan Tax System}

The Moroccan tax system has evolved since the end of the 19th century under the pressure of budgetary constraints, marked by the colonial period. The essential objective expected from this reform was the development of a modern, coherent, efficient and more Universalist tax system.

Thus, the tax administration opted for a simplification and harmonization of tax provisions. This decision resulted in a reform, the principles of which were laid down in the Framework Law No. 3-83 on tax reform adopted by the House of Representatives on 20 December 1982 and promulgated by Dahir No. 1. -83-38 of April 23, 1984, aimed mainly; the introduction of a system that ensures on the one hand a better distribution of the tax burden and a broadening of the base and the reduction of taxes, and on the other hand a reinforcement of the guarantees that the law grants to the taxpayers.

In the early nineties, an attempt to rationalize tax benefits was reflected in the establishment of an investment charter in 1996 to direct benefits to priority activities, such as well as to disadvantaged regions and are introduced into common law. Secondly, the organization of the first National Tax Conference in 1999 was an opportunity to collectively agree on a roadmap for a more modern tax system. Several reforms were also introduced by the finance laws from 2000 to 2011, which resulted in the implementation of a set of measures to 
simplify, streamline and harmonize the tax system.

Currently the main taxes are governed by two texts: The General Tax Code which governs the IS, TVA, IR, registration fees, stamp duties and the annual special tax on motor vehicles. Thus, the tax constitutes the main part of the receipts on which the budget of the State leans.

The Moroccan tax system can thus be considered as a modern system, similar to what is practiced in countries with an open economy that favor competitiveness. It would therefore be essential to ensure that the tax is not considered as a constraint, hindering the national production, but it is also perceived as a factor of solidarity and social and public stability.

Indeed, the stability of tax revenues over time is also important to maintain the continuity of the government's fiscal policies. If tax revenues tend to fluctuate over time, they become a source of risk and impose another factor of economic inefficiency on the country, which has a negative impact on government programs.

Thus, for a tax system to be productive, it must include stable taxes that guarantee consistent revenues and resources, not subject to economic conditions, and elastic taxes that allow profitability in line with economic conditions. For a tax system to provide stable revenue for its government, it is desirable that tax revenues can automatically respond to increases in national GDP.

In this sense, the assessment of the relationship between tax revenues and GDP should give an overall picture of the stability of the Moroccan tax system. This understanding could help the government plan tax reforms to stimulate inclusive growth.

\section{Measuring Stability of Tax Revenue: An Empirical Review}

The study by V. William and his associates (1973) makes a distinction between three concepts of fiscal stability, including the stability of revenues, the growth of yields, and the countercyclical stabilizing influence of taxes. The purpose of this study is to revive the criterion of stability and to measure the performance of different taxes (total revenues, IR, IS, TIC), for 19 countries over the period (1952-1970), according to three criteria; the stability of tax revenues, revenues growth and contra-cyclic stabilizing influence.

According to the authors, the stability of fiscal performance means predictable and smooth growth over time. Although predictability is helpful, it is not enough. In fact, the major part of most budgets concerns commitments in long-term programs as well as other rigid obligations. These needs must be met through a regular revenue stream. Therefore, stability can be measured by the degree of matching of tax yield to growth over the long term.

Operationally, the index of stability (z) is defined as the inverse of the standard deviation (residual variation) of the logarithm of tax revenues $(\mathrm{R})$ regressed on time $(\mathrm{t})$ :

$$
\begin{gathered}
z=\frac{1}{S_{\ln R}} \\
S_{l n R}=\sqrt{\frac{\sum(\widehat{\ln R}-\ln R)^{2}}{n-2}}
\end{gathered}
$$

The growth path is defined by the least squares regression of the logarithm of revenues over time.

$$
\ln R=\ln a+g t
$$

A higher z-index indicates a greater stability of tax revenues. If the tax yield increased by exactly the same percentage each year, the yields would be on the growth path and the stability index would move towards positive infinity. The lower limit is zero. In the empirical results, the index ranged between 1 and 51 .

\subsection{Measuring the Revenue Growth Rate}

The income elasticity coefficient of long-term revenue was also estimated by Groves-Kahn (1952). Thus, the coefficient of elasticity is $e_{1}$ in the regression equation:

$$
\log R=\log c+e_{1} \log Y
$$

It is expected that $\mathrm{g}$ and $e_{1}$ be highly correlated. Both g's and $e_{1}$ could go from positive infinity to negative infinity. In fact, all were found to be positive, $e_{1}$ never exceeding 7.35 and g not exceeding $19 \%$.

\subsection{Measuring the Cyclic Stabilizing Influence}

In order to measure short-term performance or the cyclical performance of various taxes, the authors used a method similar to the regression Groves-Kahn (1952), substituting the logarithms of the first differences of R 
and $\mathrm{Y}$, since most year-to-year changes are negative. Similar results can be obtained by regressing the annual percentage changes of $\mathrm{R}$ and $\mathrm{Y}$.

$$
\frac{\Delta R}{R}=d+e_{S} \frac{\Delta Y}{Y}
$$

Similarly, the slope coefficient $\left(e_{s}\right)$ can be defined as the average coefficient of income elasticity of short-run receipts. The empirical results that follow will show that this coefficient is very unstable.

To be an effective stabilizer, a tax must respond reliably and strongly when income changes. V. William and his associates (1973) have concluded that the correlation coefficient, $r$, is a better indicator of cyclical stabilization performance. Thus, $r$ can be interpreted as a stabilizing influence index. A higher $r$ indicates a better performance. However, fiscal policy has to deal with unemployment, inflation, imbalance and balance of payments growth as well as income instability. A certain lag in the fiscal response of rising incomes can be desirable so that the recovery of a recession would not be slowed down. The empirical results actually represent a six-month lag. The findings of this paper suggest that the best performers according to stability, growth and stabilizing influence criteria were; the fuel tax, the personal income tax and the corporation tax.

However, the Braun (1988) study - aiming to verify whether the aggregated data of state tax revenues are characterized by a deterministic trend or a pattern- found that the traditional measure of fiscal stability is subject to data mis-specification, and provides neither an accurate measure of stability nor an optimal forecast. It suggests that a better set of tax structures can be derived using the portfolio approach based on the random walk model, which considers fiscal stability synonymous with predictability.

\subsection{Stationarity Test}

Dickey-Fuller's estimation model for tax revenues leads to the special case of non-stationarity, «the random walk»;

Where

$$
w_{t}=\emptyset * \text { Trend }+p_{1} * w_{t-1}+\varepsilon_{t}
$$

$w_{t}$ : First difference in the log of tax revenues;

$\varepsilon_{t}$ : Error;

$\emptyset$ : Coefficient of the trend;

$p_{1}$ : Autoregressive parameter.

The null hypothesis to test is $\left(\varnothing, p_{1}\right)$

The stationarity test results of the model indicate that the appropriate model is ARIMA $(1,1,1)$. The measure of absolute forecast accuracy the "Root Mean Square Error (RMSE)" is calculated for each model for the years 1985-87. As a result, the absolute forecast accuracy of the random walk model is found to be the highest (ie the RMSE is smaller) for every tax revenue category. Although the absolute measure of accuracy shows that the random walk model is the best, it does not specify in which extent.

\section{Measuring Stability of Tax Revenue: An Empirical Review}

In this section we will proceed by an empirical measure of each of the criteria defined by V. William and his associates (1973), including stability (z), growth rate $(\mathrm{g})$ and stabilizing influence $(\mathrm{r})$ for Moroccan tax revenues (TVA, IS, IR and TIC), over the period 1990-2017. Long-term $\left(e_{1}\right)$ and short-term $\left(e_{s}\right)$ income elasticities were also estimated. The results are summarized in the following table:

\begin{tabular}{|c|c|c|c|c|c|}
\hline & Tax revenues & TVA & IR & IS & TIC \\
\hline Stability index (z) & 10,89 & 7,53 & 6,22 & 4,56 & 10,87 \\
\hline Average growth rate ( $\mathrm{g}$ in $\%$ ) (variation of $\mathrm{Y}$ per unit of time) & 6,2 & 8,0 & 8,3 & 10,0 & 3,4 \\
\hline Coefficient of correlation (r) & 0,99 & 0,98 & 0,98 & 0,96 & 0,97 \\
\hline Short-term elasticity coefficient $\left(e_{1}\right)$ & 1,16 & 1,48 & 1,54 & 1,85 & 0,63 \\
\hline Long-term elasticity coefficient $\left(e_{s}\right)$ & 0,62 & 0,95 & 1,39 & 1,77 & $-0,02$ \\
\hline
\end{tabular}

Table 1. Stability, growth and stabilizing influence of tax revenues 
Table 2. Correlation analysis of tax stability indices

\begin{tabular}{cccccc}
\hline & $\mathrm{z}$ & $\mathrm{g}$ & $\mathrm{r}$ & $e_{s}$ \\
$\mathrm{z}$ & 1 & & & & \\
$\mathrm{~g}$ & $-0,911196199$ & 1 & & \\
$\mathrm{r}$ & 0,489757379 & $-0,19953322$ & 1 & \\
$e_{s}$ & $-0,908661509$ & 0,99991943 & $-0,19888206$ & 1 \\
$e_{1}$ & $-0,939625939$ & 0,98197003 & $-0,2990335$ & 0,98002694 \\
\hline
\end{tabular}

The analysis of all the indicators over the period 1990-2017 demonstrates a good performance of Moroccan tax revenues in terms of stability. Overall, the state's most stable source of income is TIC, followed by the TVA, then the IR and finally the IS. Those results are equivalent to the findings of the study of V. William and his associates (1973).

The stability index (z) varies between 4.56 for the IS and 10.87 for the ICT during the period studied. This index has a strong negative correlation with revenues growth $(\mathrm{g})$ and short-term $\left(\mathrm{e}_{\mathrm{s}}\right)$ and long-term income elasticities $\left(e_{1}\right)$ for all taxes. Thus, the average income growth varies between $3.4 \%$ for TIC and $10 \%$ for the IS during the same period, the short-term tax revenues elasticities coefficients in varies between 0.63 for the TIC and 1.85 for the long-term elasticities coefficients range from -0.02 for TIC to 1.77 for the IS.

These results show that strong tax revenue stability (low dispersion coefficient) is equivalent to weaker yield growth and lower income elasticity in the short and long run. Thus, the Moroccan tax system includes stable taxes generating a constant income, ie TIC and TVA, as well as elastic taxes in correlation with economic growth, notably the IS and the IR.

It should be noted that the short-term tax income elasticities should be improved by taking into account the difference between the tax deduction and the recording in the budget of certain taxes, notably the IS. However, V. William and his associates (1973) believe that such an adjustment will be inappropriate for a cyclical stabilization index.

\section{Conclusion}

This paper gives a retrospective analysis of the mains tax reforms in Moroccan since the end of the 19th century. It shows that the Moroccan tax system has become a modern system, which aligns with the standards of countries with an open economy. For a tax system to be productive, it must include stable taxes that guarantee consistent revenues and resources, independents from economic conditions, and elastic taxes that allow profitability in line with economic conditions. Moreover, for a tax system to provide stable revenue for its government, it is desirable that tax revenues can automatically respond to increases in national GDP. The assessment of the relationship between tax revenues and GDP in this paper gives an overall picture of the stability of the Moroccan tax system. It indicates that Moroccan tax revenues have a good performance in terms of stability over the period 1990-2017, and shows that the Moroccan tax system includes taxes that generate stable current income (TIC and TVA), as well as elastic taxes correlated with economic growth (IS and IR).

\section{References}

BG Consulting. (2003). Tax simplicity and stability: attractive to countries and investors. Concept paper, November 2003.

Braun, M. (1988). Measuring tax revenue stability with implications for stabilization policy: A note. National Tax Journal, 41(4), 595-598. Retrieved from http://www.jstor.org/stable/41788766

Conseil Economique et Social. (2012). Le système fiscal marocain, développement économique et cohésion sociale. Auto-Saisine $\quad n^{\circ} 9 / 2012$. $\quad$ Retrieved http://www.ces.ma/Documents/PDF/CES_Rapport_Fiscalite-VF.pdf

Groves M., \& Kahn, C. H. (1952). The Stability of State and Local Tax Yields. Amer. Econ. Rev., 42, 87-102. Retrieved from https://www.jstor.org/stable/1914417

OCDE. (2010). Compétitivité et développement du secteur privé: Maroc 2010 Stratégie de développement du climat des affaires.

Piper, J. (2015). Stability in tax. The Association of Chartered Certified Accountants, May 2015.

Selma, N. S. (n. d.). What is a competitive fiscal regime for foreign investment? With special reference to Namibia and Botswana. University of DUNDEE. Retrieved from 
https://www.eisourcebook.org/cms/What\%20is\%20a\%20Competitive\%20Fiscal\%20Regime\%20for\%20For eign\%20Investment.pdf

Wilford, W. (1965). State tax stability criteria and the revenue-income elasticity coefficient reconsidered. National Tax Journal, 18(3), 304-312. Retrieved from https://www.jstor.org/stable/i40084212

William, W. M., Anderson, O. D., \& Lamb, K. (1973). The stability, growth and stabilizing influence of state taxes. National Tax Journal, 26(2), 267-274. Retrieved from http://www.jstor.org/stable/41791878

Note

Note 1. Braun, M. (1988). Measuring tax revenue stability with implications for stabilization policy: A note. National Tax Journal, 41(4), 595-598. Retrieved from http://www.jstor.org/stable/41788766

\section{Appendix A. The stability index (z)}

Regression statistics: $\ln R=\ln a+g t$

\begin{tabular}{lccccc}
\hline & Tax revenues & TVA & IR & IS & TIC \\
\hline Coefficient of multiple determination & 0,98484735 & 0,98077061 & 0,97453865 & 0,96726204 & 0,95223528 \\
Coefficient of determination $\mathrm{R}^{\wedge} 2$ & 0,9699243 & 0,96191099 & 0,94972559 & 0,93559584 & 0,90675204 \\
Coefficient of determination $\mathrm{R}^{\wedge} 2$ & 0,96876755 & 0,96044603 & 0,94779195 & 0,93311876 & 0,90316558 \\
Standard error & 0,09180557 & 0,13276148 & 0,16072701 & 0,21931175 & 0,09199531 \\
\hline Observations & & & 28 & & \\
\hline
\end{tabular}

\section{Appendix B. Revenue growth rate}

Regression statistics: $\log R=\log c+e_{1} \log Y$

\begin{tabular}{lccccc}
\hline & Tax revenues & TVA & IR & IS & TIC \\
\hline Coefficient of multiple determination & 0,99139188 & 0,98897578 & 0,97317841 & 0,9737419 & 0,95175437 \\
Coefficient of determination $\mathrm{R}^{\wedge} 2$ & 0,98285786 & 0,97807309 & 0,94707622 & 0,94817328 & 0,90583638 \\
Coefficient of determination $\mathrm{R}^{\wedge} 2$ & 0,98219855 & 0,97722975 & 0,94504069 & 0,94617994 & 0,9022147 \\
Standard error & 0,0301008 & 0,0437467 & 0,07161848 & 0,08544096 & 0,04014874 \\
\hline Observations & & & 28 & & \\
\hline
\end{tabular}

\section{Appendix C. Cyclic Stabilizing Influence}

Regression statistics: $\frac{\Delta R}{R}=d+e_{S} \frac{\Delta Y}{Y}$

\begin{tabular}{lccccc}
\hline & Tax revenues & TVA & IR & IS & TIC \\
\hline Coefficient of multiple determination & 0,33721698 & 0,41928776 & 0,40345006 & 0,36335254 & 0,01556263 \\
Coefficient of determination $\mathrm{R}^{\wedge} 2$ & 0,11371529 & 0,17580223 & 0,16277195 & 0,13202507 & 0,0002422 \\
Coefficient of determination $\mathrm{R}^{\wedge} 2$ & 0,0782639 & 0,14283432 & 0,12928283 & 0,09730607 & $-0,03974812$ \\
Standard error & 0,06362044 & 0,07563563 & 0,11524825 & 0,16627498 & 0,05742165 \\
\hline Observations & & & 28 & & \\
\hline
\end{tabular}

\section{Copyrights}

Copyright for this article is retained by the author(s), with first publication rights granted to the journal.

This is an open-access article distributed under the terms and conditions of the Creative Commons Attribution license (http://creativecommons.org/licenses/by/4.0/). 